\title{
KAJIAN KONSEP ARSITEKTUR SELUBUNG PADA BANGUNAN MASJID AT TIN JAKARTA
}

\author{
${ }^{1}$ Muhammad Al Fatih, ${ }^{2}$ Anisa \\ ${ }^{1}$ Universitas Muhammadiyah Jakarta, ${ }^{2}$ Universitas Muhammadiyah Jakarta \\ muh.alfatih55@gmail.com ${ }^{1}$, anisa@ftumj.ac.id²
}

Informasi Naskah

Diterima: 10/03/2021; Disetujui terbit: 14/06/2021; Diterbitkan: 30/06/2021;

http://journal.uib.ac.id/index.php/jad

\begin{abstract}
ABSTRAK
Selubung bangunan adalah elemen bangunan yang menyelubungi bangunan, yaitu dinding dan atap tembus atau yang tidak tembus cahaya dimana sebagian besar energi thermal berpindah melalui elemen tersebut. Masjid adalah rumah tempat ibadah umat Islam atau Muslim. Masjid artinya tempat sujud, sebutan lain yang berkaitan dengan masjid di Indonesia adalah musholla, langgar atau surau. Dalam mendesain masjid tidak hanya dilihat dari design interior maupun eksteriornya, Faktor kenyamanan juga penting dalam mendesain masjid, agar masyarakat sekitar maupun orang lain yang ingin beribadah ditempat tersebut merasa nyaman. Faktor kenyamanan tidak harus menggunakan AC sebagai penghawa suhu agar menjadi dingin atau lampu-lampu yang membuat terlihat terang dalam siang hari. Untuk menghasilkan faktor kenyamanan dapat juga dilakukan dengan secara alami dengan pemanfaatan selubung bangunan pada masjid. Studi kasus pada penelitian ini ialah masjid At-Tin yang berlokasi di Jakarta Timur. Metode yang digunakan pada penelitian ini ialah menggunakan métode deskriptif kualitatif berupa kata-kata. Penelitian ini bertujuan agar dapat memahami tentang arsitektur selubung, dapat memahami penerapan arsitektur selubung pada bangunan masjid dan dapat memahami elemen apa saja yang digunakan terkait arsitektur selubung pada bangunan masjid.
\end{abstract}

Kata Kunci: Selubung bangunan, Masjid

\section{ABSTRACT}

A building envelope is a building element that envelops a building, namely walls and roofs that are translucent or opaque where most of the thermal energy is transferred through these elements. A mosque is a place of worship for Muslims or Muslims. Mosque means a place of prostration, other terms related to mosques in Indonesia are musholla, langgar or surau. In designing a mosque, it is not only seen from its interior and exterior design, the comfort factor is also important in designing a mosque, so that the surrounding community and other people who want to worship in that place feel comfortable. The comfort factor does not have to use the air conditioner as an air conditioner to cool it or the lights that make it look bright during the day. To produce the comfort factor, it can also be done naturally by using the building envelope in the mosque. The case study in this research is the At-Tin mosque located in East Jakarta. The method used in this study is to use a qualitative descriptive method in the form of words. This study aims to be able to understand about the envelope architecture, to understand the application of the envelope architecture in the mosque building and to understand what elements are used in relation to the envelope architecture in the mosque building. 


\section{Pendahuluan}

Selubung bangunan terdiri dari komponen tak tembus cahaya (misalnya dinding) dan sistem fenestrasi atau komponen tembus cahaya (misalnya jendela) yang memisahkan interior bangunan dari lingkungan luar. Selubung bangunan memberikan perlindungan terhadap pengaruh lingkungan luar yang tidak dikehendaki seperti panas, radiasi, angin, hujan, kebisingan, polusi dll. Selubung bangunan memiliki peran penting dalam mengurangi konsumsi energi untuk pendinginan dan pencahayaan.

Masjid adalah rumah tempat ibadah umat Muslim. Masjid artinya tempat sujud, dan masjid yang berukuran kecil disebut musholla, langgar atau surau. Selain tempat ibadah masjid juga merupakan pusat kehidupan komunitas muslim. Kegiatan-kegiatan perayaan hari besar, diskusi, kajian agama, ceramah dan belajar Al Qur'an sering dilaksanakan di Masjid. Bahkan dalam sejarah Islam, masjid turut memegang peranan dalam aktivitas sosial kemasyarakatan. Membangun masjid harus berbeda dengan membangun sebuah rumah atau tempat tinggal apa pun. Karena masjid merupakan tempat ibadah, maka nuansa spritual yang mewarnai bangunan masjid tersebut harus di perhatikan. Segala hal yang memperlancar jalannya pelaksanaan ibadah dan aktivitas lain yang menjadi ciri khas dan karakter masjid juga harus di perhatikan. Jangan sampai mengunggulkan design interior atau eksterior masjid dengan tanpa memperhatikan karakter masjid yang mempunyai peran dan multifungsi dalam membina dan membangun masyarakat.

Dalam mendesain masjid tidak hanya dilihat dari design interior maupun eksteriornya, Faktor kenyamanan juga penting dalam mendesain masjid, agar masyarakat sekitar maupun orang lain yang ingin beribadah ditempat tersebut merasa nyaman. Faktor kenyamanan tidak harus menggunakan AC sebagai penghawa suhu agar menjadi dingin atau lampu-lampu yang membuat terlihat terang dalam siang hari. Untuk menghasilkan faktor kenyamanan dapat juga dilakukan dengan secara alami dengan pemanfaatan selubung bangunan pada masjid.

Pemanfaatan selubung bangunan pada masjid bisa digunakan dengan baik jika penggunaan dan penempatannya sesuai. Untuk penempatan bukaan atau jendela sebisa mungkin diletakan di sisi bangunan yang menghadap ke arah utara-selatan. Alasannya adalah agar mendapatkan cahaya matahari yang tidak berlebihan, Bagian selubung bangunan yang terdapat bukaan atau jendela tidak langsung terkena oleh pancaran sinar matahari yang mengakibatkan radiasi matahari yang sangat tinggi. Dengan adanya bukaan pada bagian utara-selatan dimaksudkan agar mendapatkan pencahayaan alami yang membuat pengguna didalamnya merasa nyaman.

Adapun perumusan masalah yang didapatkan dalam penelitian ini adalah mengenai konsep arsitektur selubung itu sendiri, bagaimana penerapannya pada bangunan masjid dan biasanya elemen apa saja yang digunakan sebagai selubung pada bangunan masjid.

\section{Kajian Pustaka}

Selubung bangunan adalah elemen bangunan yang menyelubungi bangunan , yaitu dinding dan atap tembus atau yang tidak tembus cahaya dimana sebagian besar energi thermal berpindah melalui elemen tersebut (Afrianti, 2018). 
(Peraturan Gubernur no.38/2012) Menjelaskan dalam buku yang berjudul "Vol.1 Selubung Bangunan" Selubung bangunan terdiri dari komponen tak tembus cahaya (misalnya dinding) dan sistem fenestrasi atau komponen tembus cahaya (misalnya jendela) yang memisahkan interior bangunan dari lingkungan luar. Selubung bangunan memberikan perlindungan terhadap pengaruh lingkungan luar yang tidak dikehendaki seperti panas, radiasi, angin, hujan, kebisingan, polusi dll.

Tujuan utama dari selubung bangunan adalah untuk melindungi penduduk dari luar lingkungan hidup. Sistem fasad biasanya statis, fasad dirancang untuk menanggapi banyak skenario dan melakukan fungsi yang dapat bertentangan satu sama lain: pencahayaan vs efisiensi energi, ventilasi terhadap pandangan dan pembangkit energi (Kensek, 2011) dengan jurnalnya yang berjudul "Environment control system for sustainable design : A methodology for testing, simulating and comparing kinetic façade system".

(Subiyantoro, 2008) dalam jurnalnya yang berjudul "Pengelolaan (elemen) selubung bangunan dalam konsep arsitektur berkelanjutan" menjelaskan bahwa secara umum elemen selubung bangunan sudah disinggung dalam bahasan diatas yaitu atap, dinding dan lantai. Bagian yang mempunyai variasi paling besar dalam kehadirannya adalah dinding. Dinding dalam hal ini termasuk semua bagian yang menjadi elemen penyusun dinding tersebut. Sebagai pembatas aktivitas dinding mempunyai peranan visual sampai dengan kenyamanan termal.

Mendapatkan panas matahari melalui selubung bangunan merupakan bagian besar dari beban panas yang diserap oleh system pendingin bangunan sehingga harus mengeluarkan energi yang besar pula. Untuk meminimalkan panas matahari masuk kedalam bangunan adalah dengan mengorientasikan bangunan untuk menghindari timur dan barat. Penggunaan warna cerah juga dapat meminimalisir penyerapan panas melalui selubung bangunan (Kusumawati, 2018).

(Peraturan Gubernur no.38/2012) dalam bukunya yang berjudul "Vol.1 Selubung Bangunan" menjelaskan tentang prinsip-prinsip yang bisa digunakan dalam mendesain suatu bangunan yaitu :

\section{Bentuk dan Orientasi}

Karena pergerakan harian dan tahunan dari matahari, radiasi matahari yang diterima selubung bangunan bervariasi untuk setiap orientasi. Untuk menghindari perolehan panas radiasi matahari yang berlebihan, permukaan utama selubung bangunan dengan jendela sedapat mungkin diorientasikan ke utara dan selatan. Ini memungkinkan jendela mendapatkan pencahayaan alami dari kubah langit dengan tetap meminimalkan perolehan panas dari radiasi matahari secara langsung.

\section{Luas Jendela}

Proporsi luas jendela memiliki pengaruh sangat besar terhadap beban pendinginan karena menentukan total perolehan panas yang masuk kedalam bangunan. Hal ini dikarenakan jendela kaca dapat memasukkan panas kedalam bangunan jauh lebih tinggi dibandingkan dengan dinding masif. Oleh karena itu rasio luas jendela terhadap dinding (WWR) yang lebih tinggi biasanya menyebabkan beban pendinginan lebih tinggi. Mengurangi luas jendela adalah salah satu solusi paling efektif untuk mengurangi beban pendinginan dan konsumsi energi bangunan secara keseluruhan.

\section{Peneduh Eksternal}

Peneduh eksternal lebih efektif dalam mengurangi perolehan panas matahari 
dibandingkan dengan peneduh internal karena dapat menghalangi radiasi matahari sebelum mencapai selubung bangunan. Peneduh eksternal perlu dirancang secara hatihati agar tidak hanya untuk mengurangi beban pendinginan tetapi juga untuk menciptakan arsitektur yang estetis, dengan tetap memperhitungkan kinerja pencahayaan alami.

\section{Reflektor Cahaya}

Reflektor cahaya (lightshelf) adalah elemen horisontal yang membagi jendela menjadi dua bagian. Jendela bagian atas untuk pencahayaan alami dan jendela bagian bawah untuk pandangan (vision) Selain berfungsi sebagai peneduh jendela bagian bawah, reflektor cahaya tersebut juga berfungsi untuk memantulkan cahaya matahari yang datang dari bagian atas jendela untuk membantu penetrasi pencahayaan alami kedalam ruangan yang jauh dari jendela.

\section{Peneduh Internal}

Peneduh internal (tirai, gorden) menahan radiasi matahari setelah melewati jendela kaca dan mencegah terjadinya radiasi matahari yang langsung mengenai penghuni dan bagian interior yang lebih dalam. Namun, peneduh internal tidak seefektif peneduh eksternal dalam mengurangi beban pendinginan. Hal ini disebabkan radiasi panas tersebut sudah terlanjur masuk ke dalam ruangan melalui kaca jendela serta diradiasikan dan dikonveksikan di dalam ruang, yang akhirnya menjadi beban pendinginan bagi sistem HVAC. Warna terang dari peneduh internal dengan lapisan reflektif lebih efektif daripada warna gelap karena lebih banyak panas dipantulkan kembali keluar melalui kaca jendela.

\section{Dinding}

Konstruksi bata dari tanah liat atau blok beton aerasi (Autoclaved Aerated Concrete - AAC) dengan plester di kedua sisi adalah aplikasi yang umum diterapkan untuk konstruksi dinding di Indonesia. Ini banyak digunakan, terutama untuk bangunan bertingkat rendah, karena harga konstruksi yang relatif murah. Belakangan ini, panel beton pracetak (precast) juga banyak digunakan untuk menggantikan konstruksi bata, terutama untuk bangunan tinggi. Dalam hal perpindahan panas, penggunaan dinding bata atau panel beton umumnya sudah cukup karena perbedaan suhu luar ruangan dengan dalam ruangan yang relatif kecil. Oleh karena itu, menambahkan lapisan insulasi pada dinding bata untuk menahan panas menjadi tidak efektif dari sisi biaya.

\section{Metode Penelitian}

Metode yang digunakan pada penelitian ini ada deskriptif kualitatif. Penelitian kualitatif ini dimaksudkan untuk mengumpulkan informasi status mengenai suatu gejala yang ada, yaitu keadaan gejala menurut apa adanya pada saat penelitian itu dilakukan.

Studi kasus yang diambil dari penelitian ini adalah berdasarkan kriteria-kriteria tertentu. Kriteria yang ditentukan ini disesuaikan dengan permasalahan yang ada dalam penelitian dan judul penelitian ini. Adapun studi kasus yang dipilih adalah Masjid At-Tin yang berlokasikan di Jl. Raya Taman Mini Pintu 1, Kelurahan Pinang Ranti, Jakarta Timur. Pembangunan Masjid At-Tin selesai pada tahun 1999 dan dibuka secara umum pada tanggal 26 November 1999.

Metode analisis yang digunakan dalam penelitian ini adalah dengan mencari datadata terkait konsep yang akan digunakan pada penelitian ini. Baik itu dari data literatur, Jurnal dan buku yang berkaitan dengan konsep penelitian semuanya dikumpulkan menjadi satu. 
Setelah semua data terkumpul, data- data yang tidak berhubungan dengan konsep yang akan di teliti akan di hapus atau tidak digunakan. kemudian peneliti mengelompokan hal-hal yang serupa menjadi kategori atau kelompok agar peneliti lebih mudah untuk melakukan pengambilan kesimpulan.

\section{Hasil dan Pembahasan}

Masjid At-Tin adalah satu di antara dua masjid megah di kawasan TMII. Masjid lainnya adalah Masjid Diponegoro. Masjid yang mulai dibangun pada April 1997 ini menempati area tanah seluas 70.000 meter persegi dengan kapasitas sekitar 9.000 orang di dalam masjid dan 1.850 orang di selasar tertutup dan plaza. Pembangunan Masjid At-Tin selesai pada tahun 1999 dan dibuka secara umum pada tanggal 26 November 1999. Alamat Lengkapnya Ada Di Jalan Raya Taman Mini Pintu 1 Taman Mini Kelurahan Pinang Ranti, Makasar, Jakarta Timur 13560.

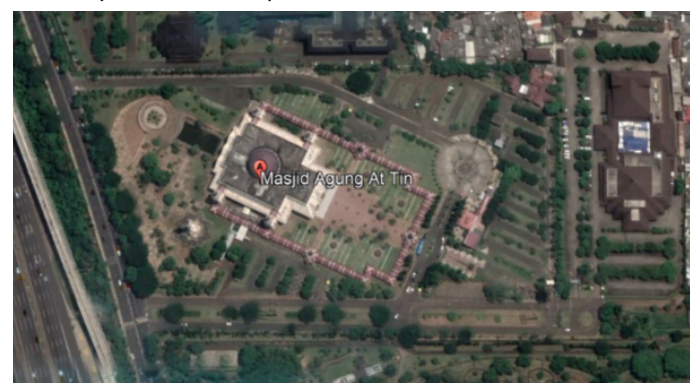

Gambar 1 : Lokasi Masjid At-Tin

Sumber : Google Earth (Akses 11/11/2020)

Pada fasad bangunan Masjid At-Tin terlihat dengan jelas terdapat sebuah pintu yang besar dan tanpa penutup apapun, Pintu besar tersebut selain berfungsi sebagai tempat masuknya orang-orang kedalam ruangan difungsikan juga sebagai tempat masuknya sirkulasi udara dan pencahayaan alami pada ruangan.

Selain pada bagian pintu utama, cahaya alami juga bisa didapatkan pada bukaan serambi yang berada di sisi bangunan. Terdapat peneduh eksternal pada bukaan serambi, dimaksudkan agar cahaya matahari tidak langsung masuk ke dalam ruangan shalat. Dinding kerawang yang berbentuk sebagai anak panah tersebut yang berada seluruh bagian masjid difungsikan juga sebagai media masuknya pencahayaan alami dan udara.

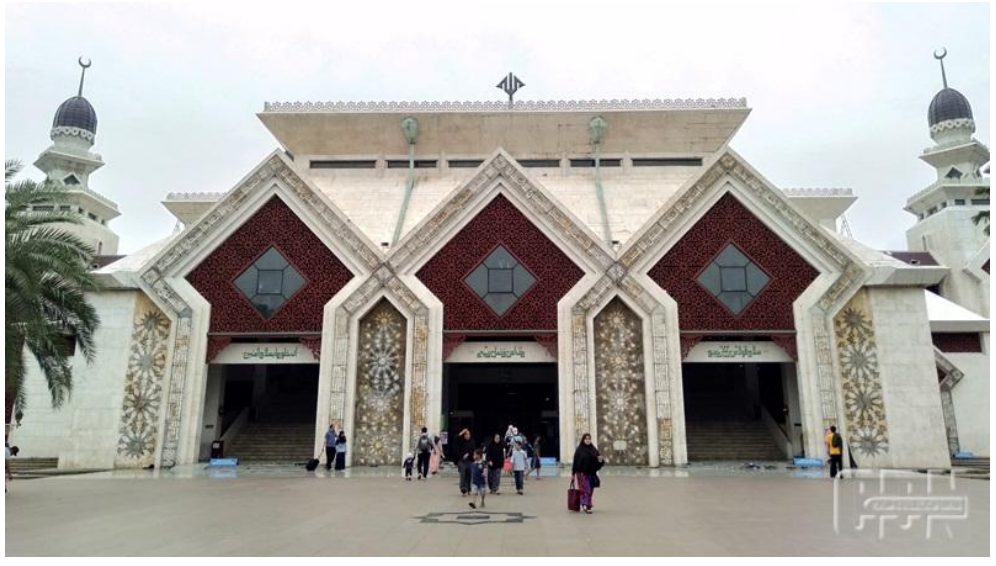

Gambar 2 : Pintu Utama

Sumber : cendananews.com (Akses 11/11/2020) 


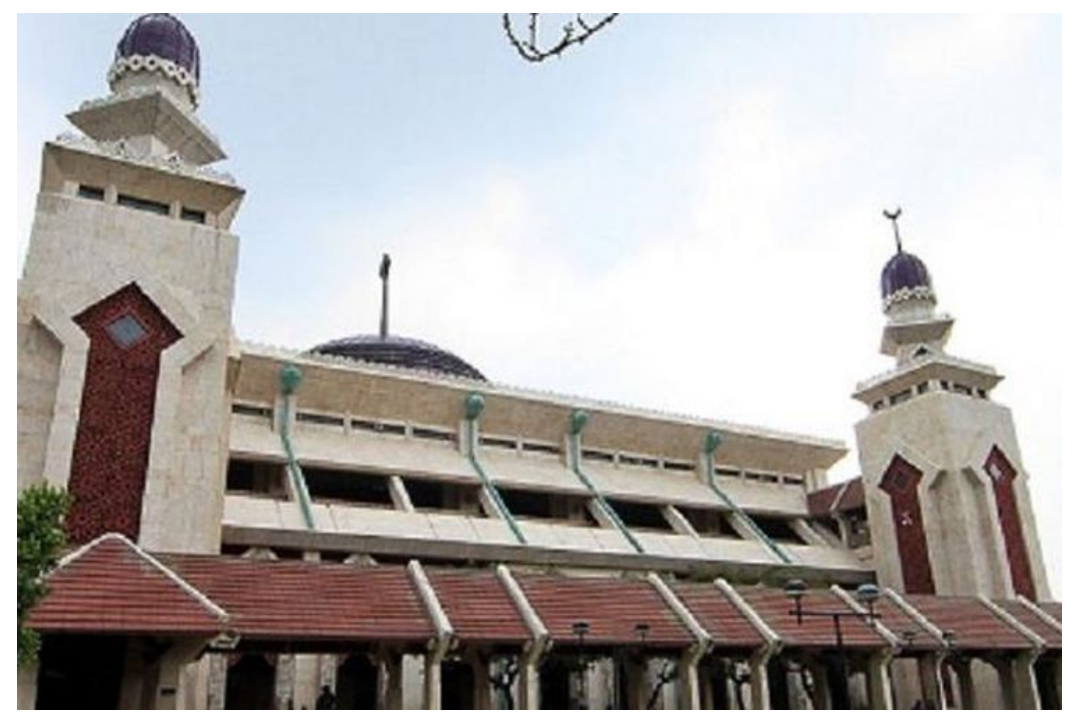

Gambar 3 : Bukaan Pada Area Serambi

Sumber : kompas.com (Akses 11/11/2020)

Pada bagian interior bangunan terdapat sebuah pencahayaan alami yang didapat melalui bukaan yang ada pada bagian kubah. Pencahayaan dihadirkan melalui kaca yang memiliki aneka warna (biru, kuning, hijau dan merah) menghasilkan komposisi warna yang elegan, sehingga hal ini menghasilkan pengalaman sinematis terhadap para jamaah.

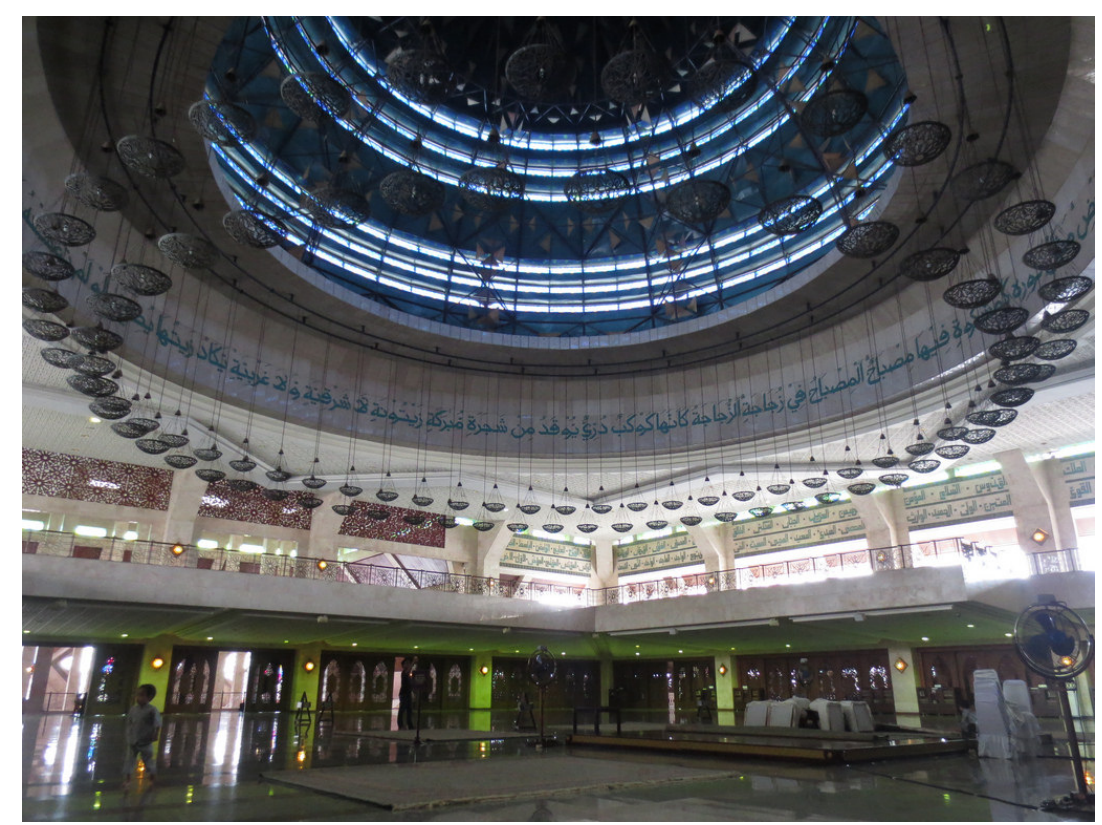

Gambar 4 : Bukaan Pada kubah Masjid

Sumber : wordpress.com (Akses 11/11/2020)

Mencoloknya lekukan, konstruksi, dan ornamen yang berbentuk anak panah pada tiap bagian masjid ini memberikan gambaran bahwa rancang bangun masjid At Tin didesain se-minimal mungkin untuk mengekspos elemen estetis terputus dengan mengedepankan gerakan geometris yang terus bersambung seperti yang tergambar dalam sudut masing-masing anak panah yang saling berhubungan. Bentuk anak panah 
ini memiliki makna agar umat manusia tidak pernah berhenti mensyukuri nikmat Allah s'eperti terlukis dalam bentuk anak panah mulai dari titik awal hingga titik akhir.

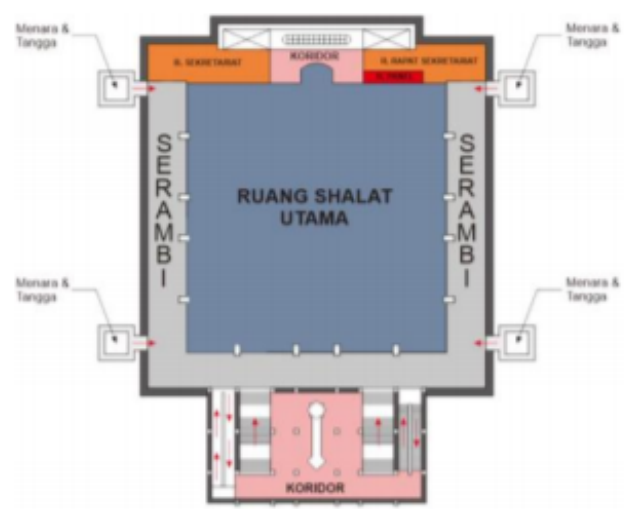

Gambar 5 : Denah Masjid At-Tin

Sumber : Jurnal ilmiah ARJOUNA (Akses 11/11/2020)

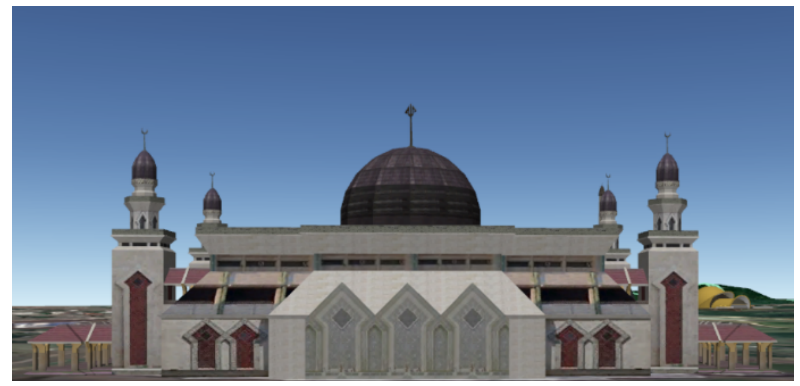

Gambar 6 : Tampak Masjid At-Tin

Sumber : Dokumen Pribadi

\section{Analisis}

Analisis dilakukan pada Masjid At-Tin yang berlokasi di Jakarta Timur, Analisis dilakukan berdasarkan prinsip selubung bangunan. Selubung bangunan terdiri dari komponen tak tembus cahaya (misalnya dinding) dan sistem fenestrasi atau komponen tembus cahaya (misalnya jendela) yang memisahkan interior bangunan dari lingkungan luar. Selubung bangunan memberikan perlindungan terhadap pengaruh lingkungan luar yang tidak dikehendaki seperti panas, radiasi, angin, hujan, kebisingan, polusi dll (Peraturan Gubernur no.38/2012. Vol.1 Selubung Bangunan). Prinsip-prinsip desain yang akan digunakan dalam analisis terkait selubung bangunan ini diantaranya adalah :

- Bentuk dan Orientasi bangunan

- Luas Jendela

- Peneduh Eksternal

- Reflektor Cahaya

- Peneduh Internal

- Dinding 


\section{Bentuk dan Orientasi}

Karena pergerakan harian dan tahunan dari matahari, radiasi matahari yang diterima selubung bangunan bervariasi untuk setiap orientasi. Untuk menghindari perolehan panas radiasi matahari yang berlebihan, permukaan utama selubung bangunan dengan jendela sedapat mungkin diorientasikan ke utara dan selatan. Ini memungkinkan jendela mendapatkan pencahayaan alami dari kubah langit dengan tetap meminimalkan perolehan panas dari radiasi matahari secara langsung.

Bentuk pada bangunan Masjid At-Tin ini adalah persegi panjang. Sisi yang Panjang diorientasikan ke arah utara dan selatan. Pada sisi ini terdapat bukaan yang fungsinya agar dapat memasukan cahaya dan udara alami kedalam bangunan dan juga meminimalisir radiasi cahaya matahri secara langsung. Sisi yang pendek diorientasikan ke arah timur dan barat. Pada sisi barat terdapat minim bukaan, karena sisi tersebut adalah mimbar dan pada sisi timur terdapat sebuah pintu masuk dan juga penempatan tangga untuk akses ke lantai atas.

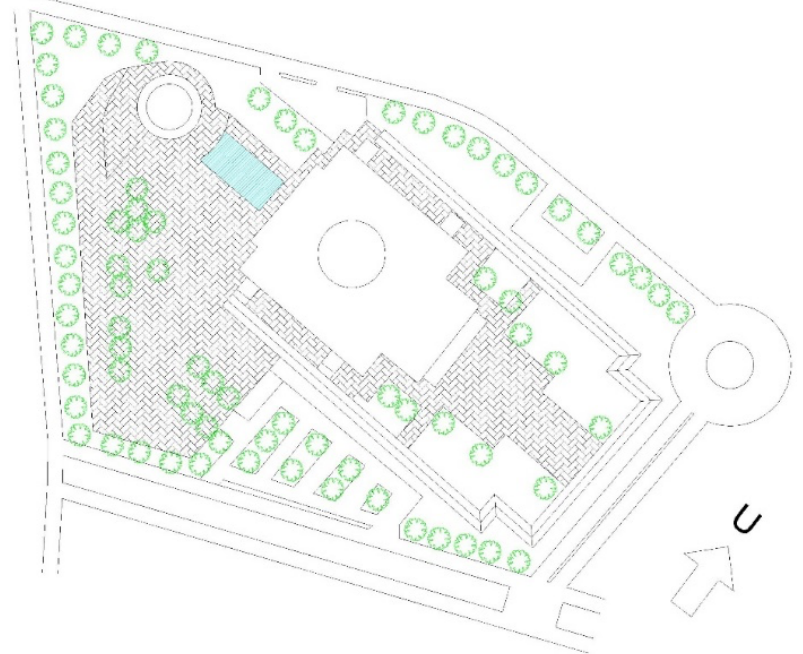

Gambar 7 : Block Plan Masjid At-Tin

Sumber : Dokumen Pribadl

\section{LUAS JENDELA}

Proporsi luas jendela memiliki pengaruh sangat besar terhadap beban pendinginan karena menentukan total perolehan panas yang masuk kedalam bangunan. Hal ini dikarenakan jendela kaca dapat memasukkan panas kedalam bangunan jauh lebih tinggi dibandingkan dengan dinding masif. Oleh karena itu rasio luas jendela terhadap dinding (WWR) yang lebih tinggi biasanya menyebabkan beban pendinginan lebih tinggi. Mengurangi luas jendela adalah salah satu solusi paling efektif untuk mengurangi beban pendinginan dan konsumsi energi bangunan secara keseluruhan.

Pada bangunan Masjid At-Tin terdapat sebuah bukaan yang berorientasikan pada sisi utara dan selatan bangunan. Bukaan pada Masjid At-Tin ini terletak pada bagian atas, tepatnya berada diatas pintu masuk pada sisi utara dan selatan. Untuk luas jendela Masjid At-Tin jika dilihat secara langsung pada bagian jendela ukurannya tidak terlalu besar dikarenakan penempatan posisinya yang berada di atas sehingga panas matahari yang masuk kedalam bangunan cukup rendah. Dengan adanya bukaan tersebut sangat efektif untuk mengurangi beban pendinginan dan konsumsi energi bangunan secara keseluruhan. 


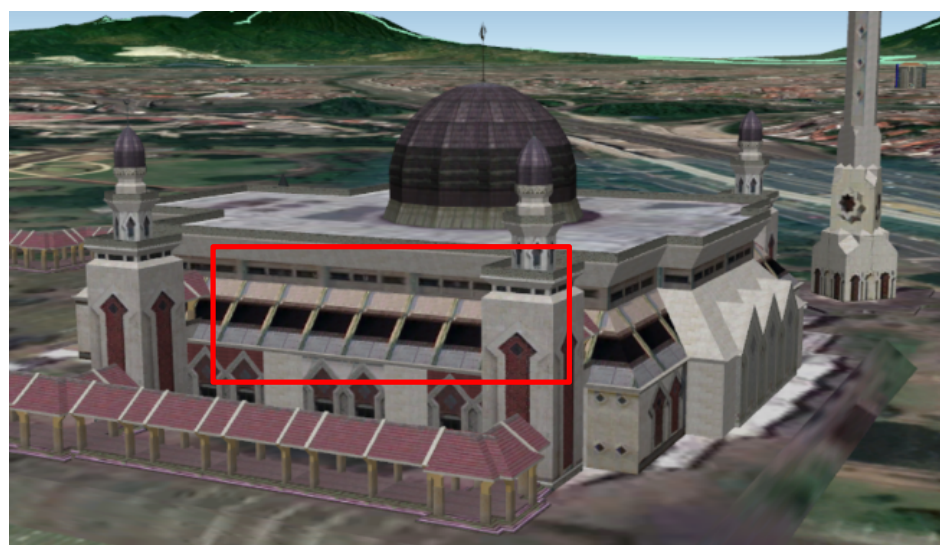

Gambar 8 : Bukaan pada Masjid At-Tin

Sumber : Dokumen Pribadil

\section{PENEDAH EKSTERNAL}

Peneduh eksternal lebih efektif dalam mengurangi perolehan panas matahari dibandingkan dengan peneduh internal karena dapat menghalangi radiasi matahari sebelum mencapai selubung bangunan. Peneduh eksternal perlu dirancang secara hatihati agar tidak hanya untuk mengurangi beban pendinginan tetapi juga untuk menciptakan arsitektur yang estetis, dengan tetap memperhitungkan kinerja pencahayaan alami.

Pada bangunan Masjid At-Tin terdapat sebuah peneduh eksternal pada sekeliling bangunannya. Peneduh eksternal yang ada pada bangunan Masjid At-Tin ini berbentuk horizontal, Peneduh eksternal ini berada pada sisi atas dan bawah bukaan yang menjulang dari bagian samping bangunan. Peneduh eksternal tersebut berfungsi sebagai penghalang radiasi sinar matahari agar tidak langsung masuk ke dalam bangunan. Selain berfungsi sebagai penghalang radiasi sinar matahari, peneduh eksternal juga dapat menambah kesan estetik terhadap bangunan.

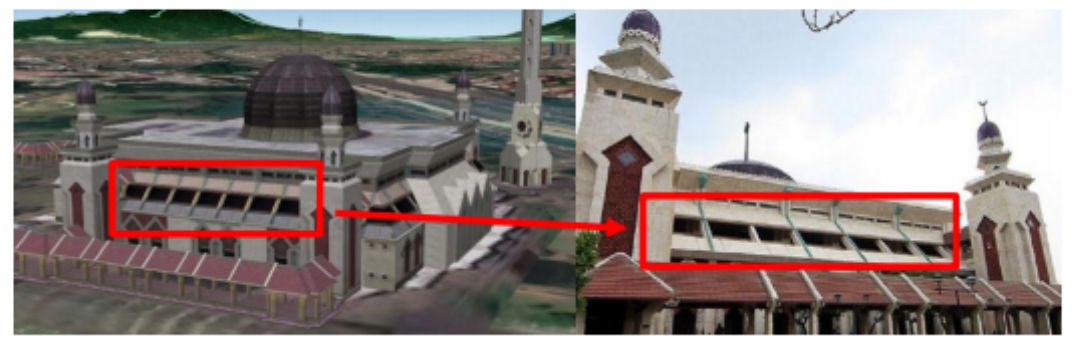

Gambar 9 : Peneduh Eksternal pada Masjid At-Tin

Sumber : Dokumen Pribadi

\section{REFLEKTOR CAHAYA}

Reflektor cahaya (lightshelf) adalah elemen horizontal yang membagi jendela menjadi dua bagian. Jendela bagian atas untuk pencahayaan alami dan jendela bagian bawah untuk pandangan (vision). Selain berfungsi sebagai peneduh jendela bagian bawah, reflektor cahaya tersebut juga berfungsi untuk memantulkan cahaya matahari yang datang dari bagian atas jendela, untuk membantu penetrasi pencahayaan alami ke dalam ruangan yang jauh dari jendela. 
Pada bangunan Masjid At-Tin ini, dapat dikatakan tidak memiliki reflektor cahaya dikarenakan jendela pada bangunan Masjid At-Tin ini hanya memiliki 1 bagian saja, sedangkan untuk reflektor cahaya merupakan elemen horizontal yang membagi jendela menjadi dua bagian yaitu bagian atas dan bagian bawah jendela. Reflektor cahaya tersebut juga berfungsi untuk memantulkan cahaya matahari yang datang dari atas jendela untuk membantu penetrasi pencahayaan alami ke dalam ruangan yang jauh dari jendela. Jadi, pada banguna Masjid At-Tin ini cahaya yang masuk ke dalam bangunan hanya masuk dari 1 bagian jendela saja sehingga tidak dapat membantu penetrasi pencahayaan alami ke dalam ruangan yang lebih jauh.

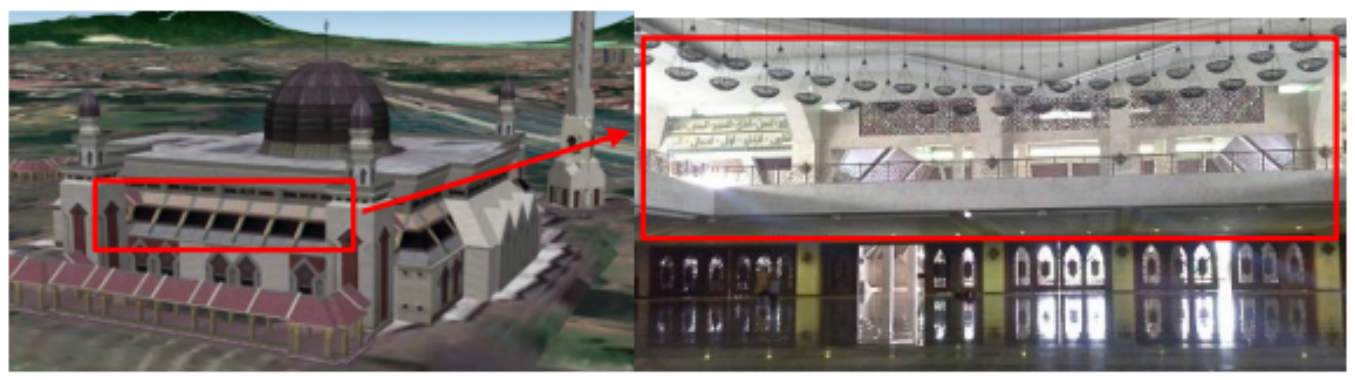

Gambar 10 : Bukaan pada Masjid At-Tin

Sumber : Dokumen Pribadi

\section{PENEDUH INTERNAL}

Peneduh internal (tirai, gorden) menahan radiasi matahari setelah melewati jendela kaca dan mencegah terjadinya radiasi matahari yang langsung mengenai penghuni dan bagian interior yang lebih dalam. Namun, peneduh internal tidak se-efektif peneduh eksternal dalam mengurangi beban pendinginan. Hal ini disebabkan radiasi panas tersebut sudah terlanjur masuk ke dalam ruangan melalui kaca jendela serta diradiasikan dan dikonveksikan di dalam ruang, yang akhirnya menjadi beban pendinginan bagi sistem HVAC. Warna terang dari peneduh internal dengan lapisan reflektif lebih efektif daripada warna gelap karena lebih banyak panas dipantulkan kembali keluar melalui kaca jendela.

Pada bangunan Masjid At-Tin ini terlihat dengan jelas bahwa tidak memiliki peneduh internal. Sebagai pengganti peneduh internal untuk menahan radiasi sinar matahari, Masjid ini menggunakan desain peneduh eksternal untuk menahan radiasi sinar matahri tersebut.

\section{DINDING}

Konstruksi bata dari tanah liat atau blok beton aerasi (Autoclaved Aerated Concrete - AAC) dengan plester di kedua sisi adalah aplikasi yang umum diterapkan untuk konstruksi dinding di Indonesia. Ini banyak digunakan, terutama untuk bangunan bertingkat rendah, karena harga konstruksi yang relatif murah. Belakangan ini, panel beton pracetak (precast) juga banyak digunakan untuk menggantikan konstruksi bata, terutama untuk bangunan tinggi. Dalam hal perpindahan panas, penggunaan dinding bata atau panel beton umumnya sudah cukup karena perbedaan suhu luar ruangan dengan dalam ruangan yang relatif kecil. Oleh karena itu, menambahkan lapisan insulasi pada dinding bata untuk menahan panas menjadi tidak efektif dari sisi biaya.

Pada bangunan Masjid At-Tin dapat dilihat dengan jelas bahwa material yang digunakan pada bangunan ialah menggunakan dinding beton yang dilapisi oleh marmer 
pada bagian luarnya. Material beton ini terdapat pada seluruh bagian bangunan, selain berfungsi sebagai dinding pada bangunan, beton ini juga berfungsi sebagai penambah bentuk ornamen-ornamen pada bangunan. Dalam hal perpindahan panas, penggunaan material ini sudah cukup untuk membuat perbandingan suhu antara suhu luar ruangan dengan suhu dalam ruangan yang relatif kecil.

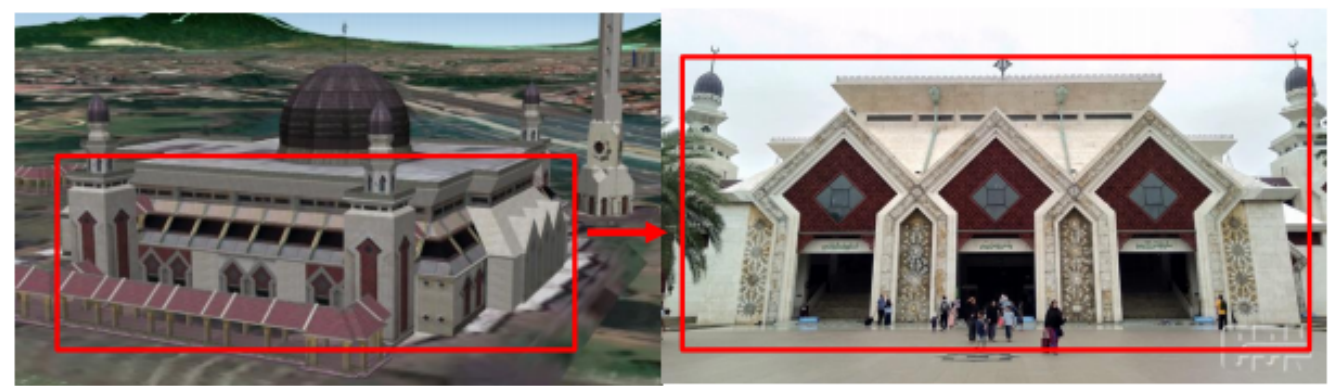

Gambar 11 : Material Dinding pada Masjid At-Tin

Sumber : Dokumen Pribadi

\section{Kesimpulan}

Kesimpulan yang didapat dari penelitian ini adalah pada Masjid At-Tin dalam prinsip desain bentuk dan orientasi ini sesuai, dikarenakan bentuk masa bangunan pada masjid ini berbentuk persegi panjang. Penempatan orientasi bukaan lebih banyak diletakan pada sisi panjang bangunan yaitu sisi utara dan selatan sedangkan pada sisi pendek bangunan yaitu sisi timur dan barat di gunakan sebagai penempatan mimbar dan pintu masuk. dengan penempatan orientasi bukaan menghadap sisi utara dan selatan agar dapat meminimalisir radiasi cahaya matahari secara langsung.

Pada Masjid At-Tin dalam prinsip desain yaitu luas jendela ini sesuai dengan standar yang ada dikarenakan ukuran bukaan yang tidak terlalu besar yang terletak pada bagian atas pintu-pintu pada sisi utara dan selatan. Dengan ukuran jendela yang tidak terlalu besar membuat matahari yang masuk kedalam bangunan cukup rendah. Dengan adanya bukaan tersebut sangat efektif untuk mengurangi beban pendinginan dan konsumsi energi bangunan secara keseluruhan.

Pada Masjid At-Tin dalam prinsip desain yaitu peneduh eksternal ini sesuai dengan standar yang ada dikarenakan pada bangunan ini memiliki peneduh eksternal yang dimana berfungsi sebagai penghalang radiasi sinar matahari agar tidak langsung masuk kedalam bangunan.

Pada Masjid At-Tin dalam prinsip desain yaitu reflektor cahaya ini tidak sesuai dengan standar yang ada dikarenakan pada bangunan ini tidak memiliki reflector cahaya yang dimana berfungsi untuk memantulkan cahaya matahari yang datang dari atas jendela untuk membantu penetrasi pencahayaan alami kedalam ruangan yang jauh dari jendela.

Pada Masjid At-Tin dalam prinsip desain yaitu peneduh internal ini tidak sesuai dengan standar yang ada dikarenakan pada bangunan ini tidak memiliki peneduh internal yang dimana berfungsi sebagai penahan radiasi sinar matahri. Sebagai pengganti peneduh internal bangunan ini menggunakan peneduh eksternal sebagai penahan radiasi sinar matahari.

Pada Masjid At-Tin dalam prinsip desain yaitu dinding ini sesuai dengan standar yang ada dikarenakan pada bangunan ini menggunakan material dinding beton dan 
dilapisi oleh marmer pada bagian luarnya yang berfungsi untuk membuat perbandingan suhu antara suhu luar ruangan dengan suhu dalam ruangan yang relative kecil.

\section{Daftar Pustaka}

Peraturan Gubernur no 38. (2012). Vol.1 Selubung bangunan. Jakarta : Pemerintah Provinsi DKI Jakarta.

Dewidar K.M. (2013). Living Skins : A new concept of self active building envelope regulating system. Dubai : SB 13 Dubai.

Keren Kensek. (2011). Environment control system for sustainable design : A methodology for testing, simulating and comparing kinetic façade system.

Susi Afrianti. (2018). Efesiensi energi dari aspek selubung bangunan. Malang : Seminar Nasional

Heru Subiyanto. (2008). Pengelolaan (elemen) selubung bangunan dalam konsep arsitektur berkelanjutan. Jakarta : Ruang Arsitektur. 